\title{
The thyroid gland and the process of aging; what is new?
}

\author{
Adam Gesing ${ }^{1 *}$, Andrzej Lewiński ${ }^{2,3}$ and Małgorzata Karbownik-Lewińska ${ }^{1,2}$
}

\begin{abstract}
The endocrine system and particular endocrine organs, including the thyroid, undergo important functional changes during aging. The prevalence of thyroid disorders increases with age and numerous morphological and physiological changes of the thyroid gland during the process of aging are well-known. It is to be stressed that the clinical course of thyroid diseases in the elderly differs essentially from that observed in younger individuals, because symptoms are more subtle and are often attributed to normal aging. Subclinical hypo- and hyperthyroidism, as well as thyroid neoplasms, require special attention in elderly subjects. Intriguingly, decreased thyroid function, as well as thyrotropin (TSH) levels - progressively shifting to higher values with age - may contribute to the increased lifespan.

This short review focuses on recent findings concerning the alterations in thyroid function during aging, including these which may potentially lead to extended longevity, both in humans and animals.
\end{abstract}

Keywords: Thyroid gland, Aging, Subclinical thyroid dysfunction, Thyroid cancer, Longevity

\section{Introduction}

The endocrine system and particular endocrine organs, including the thyroid gland, undergo - similarly to other organ systems - crucial functional changes with aging. Numerous morphological and physiological changes of the thyroid during the process of aging are well-known [1-3]. A specificity of thyroid diseases in the elderly, differing essentially from that observed in younger subjects, relies on the presence of more subtle symptoms which are often attributed to normal aging. Therefore, subclinical hypo- and hyperthyroidism, as well as thyroid neoplasms, the prevalence of which increases with age, require special attention in elderly subjects. Interestingly, altered thyroid function may contribute to the extended longevity. The present review focuses on the newest findings concerning the alterations in thyroid function during the process of aging.

\section{Thyroid dysfunction with aging}

The process of aging affects both the prevalence and clinical presentation of hypo- and hyperthyroidism.

\footnotetext{
*Correspondence: adges7@wp.pl

'Department of Oncological Endocrinology, Medical University of Lodz, Zeligowski St., No. 7/9. Lodz 90-752, Poland

Full list of author information is available at the end of the article
}

Importantly, subclinical disturbances of thyroid function are more frequent than overt diseases in general population, as well as in elderly people $[4,5]$. Consistently, the prevalence of subclinical hypothyroidism, which is characterized by normal free thyroxine $\left(\mathrm{FT}_{4}\right)$ and elevated thyrotropin (TSH) levels, increases with aging [6-12] and ranges from 3 to $16 \%$ in individuals aged 60 years and older [13].

Although it is known that overt thyroid disorders negatively affect physical and cognitive function in elderly people - for example, overt hypothyroidism is associated with the impairment of attention, concentration, memory, perceptual functions, language, and executive functions [14], subclinical hypothyroidism is not associated with impairment of physical and cognitive function or depression in individuals aged 65 years and older, as compared to euthyroidism [15]. Also Park et al. [16] have demonstrated that subclinical hypothyroidism in elderly subjects is neither associated with cognitive impairment, depression, poor quality of life nor with metabolic disturbances. On the other hand, other studies demonstrated the presence of - at least - mild cognitive impairment in people with subclinical hypothyroidism at mean age under 65 years (reviewed in [17]). Furthermore, as reported by de Jongh et al. [15], subclinical 
hypothyroidism was also not associated with the increased overall mortality risk. Similar findings were shown by Rodondi et al. [18] who analyzed data from numerous large prospective cohorts and demonstrated that total mortality was not increased in subjects with subclinical hypothyroidism, although the risk of coronary heart disease (CHD) events and of CHD mortality increased with TSH levels $10 \mathrm{mIU} / \mathrm{l}$ or higher. Nevertheless, it should be emphasized that this analysis regarded numerous different populations (cohorts) which consisted of not only elderly people and that the effect in question, i.e. of increasing TSH level on CHD incidents was not influenced by age [18].

Undoubtedly, there are obvious indications for treatment of overt hypothyroidism. On the other hand, indications for treatment of subclinical hypothyroidism are still controversial. Despite improvement of lipid profile due to treatment of subclinical hypothyroidism, there is no clear evidence that this beneficial effect can be associated with decreased cardiovascular or all-cause mortality in elderly patients [19]. Furthermore, Parle et al. [20] have reported that L-thyroxine replacement therapy does not improve cognitive function in elderly individuals with subclinical hypothyroidism. When the natural history of subclinical hypothyroidism was evaluated in the elderly, the final results depended on the presence or absence of thyroid antibodies and on that to what extent $\mathrm{TSH}$ concentration was increased. Thus, a quite high rate of reversion of subclinical hypothyroidism to euthyroid status in adults aged at least 65 years with lower baseline TSH levels and antithyroid peroxidase antibody (TPOAb) negativity was observed [21]. In turn, higher TSH level and TPOAb positivity were independently associated with lower chance of reversion to euthyroidism [21]. Moreover, TSH levels $\geq 10 \mathrm{mIU} / \mathrm{l}$ were independently associated with progression to overt hypothyroidism [21]. Similar findings, showing that higher baseline TSH levels are associated with progression from subclinical to overt hypothyroidism and that higher TSH level (> $8 \mathrm{mIU} / \mathrm{l})$ is a predictive value for development of overt hypothyroidism, were recently reported by Imaizumi et al. [22]. On the other hand, there is strong evidence that thyroid hypofunction may contribute to increased lifespan (see further in the text). Therefore, taking into account all mentioned observations, the replacement therapy with L-thyroxine is not uniformly recommended in elderly people with subclinical hypothyroidism.

In turn, subclinical hyperthyroidism, characterized by serum TSH levels below lower limit of the reference range and normal serum $\mathrm{FT}_{4}$ levels, is observed in about $8 \%$ of individuals aged 65 years and older [23]. Subclinical hyperthyroidism may be associated in older adults with decreased bone mineral density and fractures [24], or cognitive impairment [23] (reviewed in [25]). Furthermore, subclinical hyperthyroidism is associated with increased risk of total, as well as CHD mortality and atrial fibrillation (AF) incidents [26]. The highest risks of CHD mortality and AF are observed in the case of TSH levels lower than $0.1 \mathrm{mIU} / 1$ [26]. Unexpectedly, de Jongh et al. [15] have reported that subclinical hyperthyroidism is not associated with impairment of physical and cognitive function or depression in elderly people, aged 65 years and older. These authors have also demonstrated that subclinical hyperthyroidism is not associated with the increased overall mortality risk [15]. Such results are quite difficult to explain. Presumably, that ambiguity in observations may result from differences in the number of individuals enrolled in particular studies or from follow-up duration. Interestingly, Rosario [27] has recently shown that progression of subclinical hyperthyroidism to overt hyperthyroidism in elderly patients is an uncommon observation. Nevertheless, since subclinical hyperthyroidism (and obviously, overt hyperthyroidism with increased $\mathrm{T}_{4}$ level) may lead to increased risk of total, as well as CHD mortality, patients older than 65 years, with low TSH levels - particularly in case of toxic multinodular goitre or a solitary autonomous thyroid nodule - require proper medical treatment (e.g. [11]).

It should also be stressed that during aging, genderspecific alterations in TSH and free thyroid hormone levels were observed [28]. Namely, with increasing age in males there were decreases in free thyroid hormones but not in TSH concentrations. In turn, in females, the free thyroid hormone levels were not changed with aging but TSH level increased in age-dependent manner [28].

Most recent results indicate that even in euthyroid older men with normal levels of TSH, differences in $\mathrm{FT}_{4}$ levels within the normal range predict specific health outcomes relevant to aging. For example, higher $\mathrm{FT}_{4}$ within the normal range was independently associated with frailty in euthyroid men aged $\geq 70$ years [12]. Moreover, higher $\mathrm{FT}_{4}$ levels within the normal range were associated with lower hip bone mineral density, increasing bone loss and fracture risk in postmenopausal women [29]. Therefore, it seems that further studies are required to explain whether higher $\mathrm{FT}_{4}$ levels contribute causally (or not) to the above mentioned poorer health outcomes. Moreover, it is of interest to clarify whether $\mathrm{FT}_{4}$ levels in the low-normal range could be considered as potential biomarkers for healthy aging [12].

Although numerous studies demonstrate that the increased TSH level resulting from subclinical hypothyroidism further rises with aging [6-12], other findings suggest that aging is associated - in the absence of any thyroid disease - with lower TSH levels [30-35]. It has been known that TSH secretion in response to 
thyrotropin-releasing hormone (TRH) is reduced in aging individuals, and serum TSH level is usually lower in older than in young people in response to decreased thyroid hormone concentrations, suggesting a certain level of insensitivity of thyrotrophic cells in anterior pituitary, occurring with age; moreover, nocturnal surge of TSH is - to various degree - lost in the elderly (reviewed in [1]). On the other hand, Bremner et al. [10] have recently reported that the TSH increase observed by other authors during aging - seems to be a consequence of age-related alteration in the TSH set point or reduced TSH bioactivity. Interestingly, the largest TSH increase is observed in people with the lowest TSH at baseline, and, in turn, people with higher baseline TSH levels had proportionally smaller increases in TSH concentrations [10]. It is worth adding that TRH and $\mathrm{FT}_{4}$ serum levels do not differ between young, middle-aged and elderly subjects [34].

\section{Thyroid dysfunction and longevity}

As it has been mentioned above, the alterations in levels of hormones related to pituitary-thyroid axis are associated with the process of aging and, thus, may impact longevity. However, a direction of these changes, which may lead to increased lifespan, still seems to be not fully determined [6-12,30-35].

One should emphasize that the most striking findings concerning potential contribution of TSH and thyroid hormones to lifespan regulation, were obtained in the studies performed on centenarians (and almost centenarians). In 2009, Atzmon et al. [7] published the results of studies on thyroid disease-free population of Ashkenazi Jews, characterized by exceptional longevity (centenarians). They have observed higher serum TSH level in these subjects as compared to the control group consisted of younger unrelated Ashkenazi Jews, as well as to another control group obtained from The National Health and Nutrition Examination Survey (NHANES) program of studies [7]. Therefore, these findings appear to support previous observations, indicating that serum TSH shifts progressively to higher levels with age (e.g., [36]). Moreover, the authors have observed an inverse correlation between $\mathrm{FT}_{4}$ and TSH levels in centenarians and Ashkenazi controls, and finally, they have distinctly concluded that increased serum TSH is associated with extreme longevity [7]. In another study, a role of genetic background, potentially responsible for the above-mentioned changes, was assessed [37]. It turned out that two (2) single nucleotide polymorphisms (SNPs) in TSH receptor (TSHR) gene, namely rs10149689 and rs12050077, were associated with increased TSH level in the Ashkenazi Jewish centenarians and their offspring [37].
The above-mentioned inverse correlation between FT4 and TSH in centenarians may suggest a potential role of decreased thyroid function in lifespan regulation, leading to remarkable longevity. Such a hypothesis seems to have been confirmed by the findings obtained in the Leiden Longevity Study, demonstrating the associations between low thyroid activity and exceptional familial longevity [38].

In turn, Corsonello et al. [39] have demonstrated that age is associated with a decrease in free triiodothyronine $\left(\mathrm{FT}_{3}\right)$ and $\mathrm{FT}_{4}$ but not with increased TSH levels. Moreover, children and nieces/nephews of centenarians had lower $\mathrm{FT}_{3}, \mathrm{FT}_{4}$ and $\mathrm{TSH}$ levels as compared to the agematched subjects [39]. It may, at least partially, confirm an important role of low thyroid function in the regulation of lifespan.

It should be stressed that reduced thyroid function with low levels of $T_{4}$ is associated with extended longevity also in animals [40-42]. For example, a very severe thyroid hypofunction with reduced core body temperature, as observed in Ames dwarf ( $\mathrm{df} / \mathrm{df})$ and Snell mice (characterized by mutations at the Prop- 1 and Pit-1 gene, respectively, and demonstrating a lack of growth hormone $(\mathrm{GH})$, prolactin and TSH), is considered to substantially contribute to remarkable longevity in these rodents [40]. Furthermore, severe hypothyroid Ames dwarfs and mice with targeted disruption of the growth hormone receptor/growth hormone binding protein gene (GH receptor knockout; GHRKO) with mild thyroid hypofunction, have decreased thyroid follicle size which may explain decreased thyroid hormone levels in these mutants [43].

Concluding, the findings in animals are consistent with the results obtained in humans and may confirm a relevant role of thyroid hypofunction in lifespan extension.

\section{Thyroid cancerogenesis and aging processes}

The prevalence of thyroid nodules and thyroid neoplasms is increased in the elderly. Among elderly people, males are at higher risk of cancer and thyroid cancer is more aggressive in men than in women [44].

Papillary thyroid carcinoma (PTC) is the most common endocrine malignant neoplasm in the older individuals. Women are affected by PTC two to three times more often than men [45]. Nevertheless, female-to-male ratio seems to decline with the process of aging [45]. Importantly, the mortality rate of PTC is usually higher in the elderly [46]. Presumably, it is a consequence of increased mitotic activity of these tumors and increased likelihood of distant metastases [46]. It is known that in general population patients with aggressive variants of PTC have higher risk for the metastatic disease development [47]. The potential role of NDRG2 gene expression 
in the development and progression of PTC is also raised [48]. It is worth recalling that mutated BRAF gene is an independent predicting factor of poor outcome in PTC and is related to advanced age [49].

Follicular thyroid carcinoma (FTC) occurs also often in older people and is the second most common and the second least aggressive thyroid cancer. This cancer is more likely to metastasize hematogenously to distant sites, resulting in a worse prognosis in comparison with PTC [44].

Medullary thyroid carcinoma (MTC), which derives from the parafollicular cells (C cells) of the thyroid gland, constitutes up to $5 \%$ of all thyroid malignancies. Its sporadic form, more frequent than is familial MTC, occurs more commonly in the older population [50].

Rapidly growing and typically very aggressive anaplastic (undifferentiated) thyroid carcinoma (ATC) is rare. However, one should strongly emphasize that its prevalence is considerably higher in older than in younger people. By the time of diagnosis, most patients have widespread local invasion and distant metastases. Age appears to be a strong predictor of poor prognosis in ATC [44].

\section{Conclusions}

The process of aging strongly affects entire endocrine system. Consistently, thyroid gland is also impacted by aging. One should emphasize that thyroid diseasesassociated symptoms in the elderly people are very similar to symptoms of the normal aging. Therefore, broadening the knowledge on alterations in thyroid function, which may be observed during aging, appears to be very important and constitutes a challenge for thyroid researchers, given that some specific thyroid dysfunctions may contribute to lifespan extension.

\section{Competing interests}

The authors declare that they have no competing interests.

\section{Authors' contributions}

AG wrote the draft of manuscript. AL was involved in the revision of the text. MKL supervised preparation of the final version of manuscript. All authors read and approved the final manuscript.

\section{Acknowledgements}

Preparation of this review was supported by funds (2011/N/1 and 2011/NI/7) from the Polish Mother's Memorial Hospital - Research Institute, Lodz, Poland.

\footnotetext{
Author details

${ }^{1}$ Department of Oncological Endocrinology, Medical University of Lodz, Zeligowski St., No. 7/9. Lodz 90-752, Poland. '2Department of Endocrinology and Metabolic Diseases, Polish Mother's Memorial Hospital - Research Institute, Rzgowska St., No. 281/289, Lodz 93-338, Poland. ${ }^{3}$ Department of Endocrinology and Metabolic Diseases, Medical University of Lodz, Rzgowska St., No. 281/289, Lodz 93-338, Poland.
}

Received: 12 October 2012 Accepted: 18 November 2012 Published: 24 November 2012

\section{References}

1. Lewiński A, Sewerynek E, Karbownik M: Aging processes and the thyroid gland. In Aging and Age-Related Diseases: The Basics. Edited by Karasek M. New York: Nova Science Publishers, Inc; 2006:131-172.

2. Faggiano A, Del Prete M, Marciello F, Marotta V, Ramundo V, Colao A: Thyroid diseases in elderly. Minerva Endocrinol 2011, 36:211-231.

3. Papaleontiou M, Haymart MR: Approach to and treatment of thyroid disorders in the elderly. Med Clin North Am 2012, 96:297-310.

4. Cooper DS: Thyroid disease in the oldest old: the exception to the rule. JAMA 2004, 292:2651-2654

5. Surks Ml, Ortiz E, Daniels GH, Sawin CT, Col NF, Cobin RH, Franklyn JA, Hershman JM, Burman KD, Denke MA, Gorman C, Cooper RS, Weissman NJ: Subclinical thyroid disease: scientific review and guidelines for diagnosis and management. JAMA 2004, 291:228-238.

6. Ochs N, Auer R, Bauer DC, Nanchen D, Gussekloo J, Cornuz J, Rodondi N: Meta-analysis: subclinical thyroid dysfunction and the risk for coronary heart disease and mortality. Ann Intern Med 2008, 148:832-845.

7. Atzmon G, Barzilai N, Hollowell JG, Surks MI, Gabriely I: Extreme longevity is associated with increased serum thyrotropin. J Clin Endocrinol Metab 2009, 94:1251-1254.

8. Boucai L, Surks MI: Reference limits of serum TSH and free T4 are significantly influenced by race and age in an urban outpatient medical practice. Clin Endocrinol 2009, 70:788-793.

9. Surks MI, Boucai L: Age- and race-based serum thyrotropin reference limits. J Clin Endocrinol Metab 2010, 95:496-502.

10. Bremner AP, Feddema P, Leedman PJ, Brown SJ, Beilby JP, Lim EM, Wilson SG, O'Leary PC, Walsh JP: Age-related changes in thyroid function: a longitudinal study of a community-based cohort. J Clin Endocrinol Metab 2012, 97:1554-1562.

11. Cooper DS, Biondi B: Subclinical thyroid disease. Lancet 2012, 379:1142-1154.

12. Yeap BB: Hormones and health outcomes in aging men. Exp Gerontol 2012, in press, http://dx.doi.org/10.1016/j.exger.2012.07.012.

13. Biondi B, Cooper DS: The clinical significance of subclinical thyroid dysfunction. Endocr Rev 2008, 29:76-131.

14. Kramer C, von Muhlen D, Kritz-Silverstein D, Barrett-Connor E: Treated hypothyroidism, cognitive function, and depressed mood in old age: the Rancho Bernardo Study. Eur J Endocrinol 2009, 161:917-921.

15. de Jongh RT, Lips P, van Schoor NM, Rijs KJ, Deeg DJ, Comijs HC, Kramer $\mathrm{MH}$, Vandenbroucke JP, Dekkers OM: Endogenous subclinical thyroid disorders, physical and cognitive function, depression, and mortality in older individuals. Eur J Endocrinol 2011, 165:545-554.

16. Park YJ, Lee EJ, Lee YJ, Choi SH, Park JH, Lee SB, Lim S, Lee WW, Jang HC, Cho BY, Woo Jl, Kim KW: Subclinical hypothyroidism (SCH) is not associated with metabolic derangement, cognitive impairment, depression or poor quality of life (QoL) in elderly subjects. Arch Gerontol Geriatr 2010, 50:e68-e73.

17. Begin ME, Langlois MF, Lorrain D, Cunnane SC: Thyroid function and cognition during aging. Curr Gerontol Geriatr Res 2008, doi:10.1155/2008/ 474868.

18. Rodondi N, den Elzen WP, Bauer DC, Cappola AR, Razvi S, Walsh JP, Asvold BO, lervasi G, Imaizumi M, Collet TH, Bremner A, Maisonneuve P, Sgarbi JA, Khaw KT, Vanderpump MP, Newman AB, Cornuz J, Franklyn JA, Westendorp RG, Vittinghoff E, Gussekloo J, Thyroid Studies Collaboration: Subclinical hypothyroidism and the risk of coronary heart disease and mortality. JAMA 2010, 304:1365-1374.

19. Bensenor IM, Olmos RD, Lotufo PA: Hypothyroidism in the elderly: diagnosis and management. Clin Interv Aging 2012, 7:97-111.

20. Parle J, Roberts L, Wilson S, Pattison H, Roalfe A, Haque MS, Heath C, Sheppard M, Franklyn J, Hobbs FD: A randomized controlled trial of the effect of thyroxine replacement on cognitive function in communityliving elderly subjects with subclinical hypothyroidism: the Birmingham Elderly Thyroid study. J Clin Endocrinol Metab 2010, 95:3623-3632.

21. Somwaru LL, Rariy CM, Arnold AM, Cappola AR: The natural history of subclinical hypothyroidism in the elderly: the cardiovascular health study. J Clin Endocrinol Metab 2012, 97:1962-1969.

22. Imaizumi M, Sera N, Ueki I, Horie I, Ando T, Usa T, Ichimaru S, Nakashima E, Hida A, Soda M, Tominaga T, Ashizawa K, Maeda R, Nagataki S, Akahoshi M: Risk for progression to overt hypothyroidism in an elderly Japanese population with subclinical hypothyroidism. Thyroid 2011, 21:1177-1182 
23. Ceresini G, Lauretani F, Maggio M, Ceda GP, Morganti S, Usberti E, Chezzi C, Valcavi R, Bandinelli S, Guralnik JM, Cappola AR, Valenti G, Ferrucci L: Thyroid function abnormalities and cognitive impairment in elderly people: results of the Invecchiare in Chianti study. J Am Geriatr Soc 2009, 57:89-93.

24. Turner MR, Camacho X, Fischer HD, Austin PC, Anderson GM, Rochon PA, Lipscombe LL: Levothyroxine dose and risk of fractures in older adults: nested case-control study. BMJ 2011, 342:d2238.

25. Mitrou P, Raptis SA, Dimitriadis G: Thyroid disease in older people. Maturitas 2011, 70:5-9.

26. Collet TH, Gussekloo J, Bauer DC, den Elzen WP, Cappola AR, Balmer P lervasi G, Asvold BO, Sgarbi JA, Völzke H, Gencer B, Maciel RM, Mollinaro S, Bremner A, Luben RN, Maisonneuve $P$, Cornuz J, Newman AB, Khaw KT, Westendorp RG, Franklyn JA, Vittinghoff E, Walsh JP, Rodondi N, Thyroid Studies Collaboration: Subclinical hyperthyroidism and the risk of coronary heart disease and mortality. Arch Intern Med 2012, 172:799-809.

27. Rosario PW: Natural history of subclinical hyperthyroidism in elderly patients with TSH between 0.1 and $0.4 \mathrm{mIU} / \mathrm{l}$ : a prospective study. Clin Endocrinol 2010, 72:685-688.

28. Suzuki S, Nishio S, Takeda T, Komatsu M: Gender-specific regulation of response to thyroid hormone in aging. Thyroid Res 2012, 5:1.

29. Murphy E, Gluer CC, Reid DM, Felsenberg D, Roux C, Eastell R, Williams GR: Thyroid function within the upper normal range is associated with reduced bone mineral density and an increased risk of non-vertebral fractures in healthy euthyroid postmenopausal women. J Clin Endocrinol Metab 2010, 95:3173-3181.

30. Mariotti S, Franceschi C, Cossarizza A, Pinchera A: The aging thyroid. Endocr Rev 1995, 16:686-715.

31. Chahal HS, Drake WM: The endocrine system and ageing. J Pathol 2007, 211:173-180.

32. Ferrari E, Cravello L, Falvo F, Barili L, Solerte SB, Fioravanti M, Magri F: Neuroendocrine features in extreme longevity. Exp Gerontol 2008, 43:88-94.

33. Sell MA, Schott M, Tharandt L, Cissewski K, Scherbaum WA, Willenberg HS: Functional central hypothyroidism in the elderly. Aging Clin Exp Res 2008, 20:207-210.

34. Mazzoccoli G, Pazienza V, Piepoli A, Muscarella LA, Inglese M, De Cata A, Giuliani F, Tarquini R: Hypothalamus-hypophysis-thyroid axis function in healthy aging. J Biol Regul Homeost Agents 2010, 24:433-439.

35. Over R, Mannan S, Nsouli-Marktabi H, Burman KD, Jonklaas J: Age and the thyrotropin response to hypothyroxinemia. J Clin Endocrinol Metab 2010, 95:3675-3683.

36. Hollowell JG, Staehling NW, Flanders WD, Hannon WH, Gunter EW, Spencer CA, Braverman LE: Serum TSH, T(4), and thyroid antibodies in the United States population (1988 to 1994): National Health and Nutrition Examination Survey (NHANES III). J Clin Endocrinol Metab 2002, 87:489-499.

37. Atzmon G, Barzilai N, Surks MI, Gabriely I: Genetic predisposition to elevated serum thyrotropin is associated with exceptional longevity. J Clin Endocrinol Metab 2009, 94:4768-4775.

38. Rozing MP, Houwing-Duistermaat JJ, Slagboom PE, Beekman M, Frölich M, de Craen AJ, Westendorp RG, van Heemst D: Familial longevity is associated with decreased thyroid function. J Clin Endocrinol Metab 2010, 95:4979-4984

39. Corsonello A, Montesanto A, Berardelli M, De Rango F, Dato S, Mari V, Mazzei B, Lattanzio F, Passarino G: A cross-section analysis of FT3 age-related changes in a group of old and oldest-old subjects, including centenarians' relatives, shows that a down-regulated thyroid function has a familial component and is related to longevity. Age Ageing 2010 39:723-727.

40. Brown-Borg HM: Hormonal regulation of longevity in mammals. Ageing Res Rev 2007, 6:28-45.

41. Buffenstein R, Pinto $M$ : Endocrine function in naturally long-living small mammals. Mol Cell Endocrinol 2009, 299:101-111.

42. Edrey $\mathrm{YH}$, Park TJ, Kang H, Biney A, Buffenstein R: Endocrine function and neurobiology of the longest-living rodent, the naked mole-rat. Exp Gerontol 2011, 46:116-123.

43. Gesing A, Bartke A, Masternak MM, Lewiński A, Karbownik-Lewińska M: Decreased thyroid follicle size in dwarf mice may suggest the role of growth hormone signaling in thyroid growth regulation. Thyroid Res 2012, 5:7.
44. Rukhman N, Silverberg A: Thyroid cancer in older men. Aging Male 2011, 14:91-98.

45. Kilfoy BA, Devesa SS, Ward MH, Zhang Y, Rosenberg PS, Holford TR, Anderson WF: Gender is an age-specific effect modifier for papillary cancers of the thyroid gland. Cancer Epidemiol Biomarkers Prev 2009, 18:1092-1100.

46. Toniato A, Bernardi C, Piotto A, Rubello D, Pelizzo MR: Features of papillary thyroid carcinoma in patients older than 75 years. Updates Surg 2011, 63:115-118

47. Chrisoulidou A, Boudina M, Tzemailas A, Doumala E, lliadou PK, Patakiouta F, Pazaitou-Panayiotou K: Histological subtype is the most important determinant of survival in metastatic papillary thyroid cancer. Thyroid Res 2011, 4:12.

48. Mordalska A, Latek J, Ferenc T, Pomorski L, Gałecka E, Zygmunt A, Lewinski A: Evaluation of NDRG2 gene expression in primary papillary thyroid carcinoma and in metastases of this neoplasm to regional lymph nodes. Thyroid Res 2010, 3:6.

49. Ito Y, Higashiyama T, Takamura Y, Miya A, Kobayashi K, Matsuzuka F, Kuma K, Miyauchi A: Risk factors for recurrence to the lymph node in papillary thyroid carcinoma patients without preoperatively detectable lateral node metastasis: validity of prophylactic modified radical neck dissection. World J Surg 2007, 31:2085-2091.

50. Habra M, Sarlis NJ: Thyroid and aging. Rev Endocr Metab Disord 2005, 6:145-154.

doi:10.1186/1756-6614-5-16

Cite this article as: Gesing et al:: The thyroid gland and the process of aging; what is new?. Thyroid Research 2012 5:16.

\section{Submit your next manuscript to BioMed Central and take full advantage of:}

- Convenient online submission

- Thorough peer review

- No space constraints or color figure charges

- Immediate publication on acceptance

- Inclusion in PubMed, CAS, Scopus and Google Scholar

- Research which is freely available for redistribution

Submit your manuscript at www.biomedcentral.com/submit
C) Biomed Central 